\title{
IDENTIFIKASI DAN ANALISIS MODAL SOSIAL DALAM RANGKA PEMBERDAYAAN MASYARAKAT NELAYAN DESA GANGGA DUA KABUPATEN MINAHASA UTARA
}

\author{
Otniel Pontoh \\ Staf Pengajar pada Program Studi Agrobisnis Perikanan, \\ Fakultas Perikanan dan IImu Kelautan. UNSRAT. Manado 95115.
}

\begin{abstract}
The research with aimed to identified and analyzed social capital of fisheries communities in Gangga dua village, North Minahasa District, has been conducted in 2007. Socio-culture data collected from fisheries community is consist of local value and local value system, local religious, pattern and system of production and reproduction and local politics. Data was collected by snowball sampling from community members who have in deep knowledge about socio-culture of their own community. After data collected shown the socio-culture character of fisheries community then it has been analyzed to show the social capital typology. The research shows that fisheries community in Gangga Dua village still become closed community or has a characteristic of social capital bounding. A policy related to social structure improvement is need because the social capital typology's of fisheries community in Pasauran village has been greatly influenced by various economic aspect in economic activity of their life.
\end{abstract}

\section{Keywords: Social Capital, Fisheries Community, Community Empowerment, Gangga Dua Village}

\section{PENDAHULUAN}

Masyarakat wilayah pesisir yang berprofesi sebagai nelayan hingga kini masih merupakan salah satu pelaku usaha perikanan yang berkontribusi besar terhadap masih tingginya tingkat kemiskinan masyarakat di wilayah pesisir. Dari 8090 desa pesisir yang sebagian besar dihuni masyarakat nelayan, tercatat 16,42 juta jiwa hidup dengan indeks kemiskinan sebesar 0,32. Artinya lebih kurang $32 \%$ individu di wilayah pesisir masih belum mampu memenuhi kebutuhan hidup yang mendasar (Yayasan Smeru dan BPS, 2002 dalam Departemen Kelautan dan Perikanan, 2006). Kondisi ini tentunya ironis jika dibandingkan dengan banyaknya upaya pembangunan yang telah dilakukan oleh pemerintah (BBRSE, 2005).

Berdasarkan konsep pembangunan (berbasis masyarakat) yang dikemukakan oleh Hasbullah (2006) diketahui bahwa keberhasilan pembangunan masyarakat perlu dilihat dari beberapa modal komunitas (community capital) yang terdiri dari: (a) Modal Manusia (human capital) berupa kemampuan personal seperti pendidikan, pengetahuan, kesehatan, keahlian dan keada- an terkait lainnya; (b) Modal Sumberdaya Alam (natural capital) seperti perairan laut; (c) Modal Ekonomi Produktif (produced economic capital) berupa aset ekonomi dan finansial serta aset lainnya; dan (d) Modal Sosial (sosial capital) berupa norma/nilai (trust, reciprocity, norma sosial lainnya), partisipasi dalam jaringan, pro-activity.

Beberapa literatur mengemukakan bahwa modal manusia, modal sumberdaya alam dan modal ekonomi produktif sudah banyak digarap oleh pemerintah, namun tidak demikian halnya dengan modal sosial yang selama ini masih banyak diabaikan (Cernea, 1988; Hasbullah, 2006; Jamasy, 2004).

Berdasarkan preposisi tersebut tampak bahwa ketidakberhasilan atau masih rendahnya kinerja pembangunan hingga kini dikarenakan pemerintah seringkali mengabaikan sistem sosial masyarakat yang menjadi obyek pembangunan. Pengabaian sistem sosial masyarakat lebih lanjut berakibat pada tidak dipahaminya dan tidak termanfaatkannya modal sosial masyarakat terkait.

Nelayan berdasarkan sifat usahanya memiliki ketergantungan pada sumberdaya 
alam (sumberdaya perikanan) yang sangat tinggi. Sementara itu, di beberapa perairan laut saat ini diketahui tidak lagi mampu mendukung peningkatan produktivitas usaha perikanan tangkap yang dilakukan oleh nelayan. Oleh karena itu, pemanfaatan modal sosial di masyarakat nelayan merupakan alternatif yang sangat krusial dan mendesak dalam rangka menutupi kecenderungan menurunnya sumberdaya alam tersebut. Kendala muncul tatkala diketahui belum banyak data maupun informasi ilmiah mengenai gambaran modal sosial masyarakat nelayan di Indonesia.

Penelitian ini memaparkan hasil dari suatu penelitian yang bertujuan mendapatkan gambaran tentang identifikasi dan analisis modal sosial dalam rangka pemberdayaan masyarakat nelayan. Penggambaran modal sosial dilakukan melalui kajian sosial budaya masyarakat nelayan di Desa Gangga Dua, Kabupaten Minahasa Utara, yang merupakan masyarakat nelayan yang menghadapi ancaman menipisnya sumberdaya perikanan di perairan operasionalnya.

\section{METODE PENELITIAN}

Penelitian ini dilaksanakan berdasarkan metode eksploratif dan deskriptif, dimana upaya dilakukan untuk menampilkan gambaran pola kehidupan sosial ekonomi masyarakat pesisir (Supardi, 2005).

Pendekatan studi kasus dipilih guna mempelajari organisasi sosial ekonomi dan variabel atau aspek terkait lainnya lebih mendalam. Studi kasus yaitu penelitian yang dilakukan dengan cara mempelajari suatu kasus tertentu pada objek yang terbatas (Mantjoro, 1990).

\section{Kerangka Pemikiran Penelitian}

Cox (1995) dalam Hasbullah (2006) mendefinisikan modal sosial sebagai suatu rangkaian proses hubungan antar manusia yang ditopang oleh jaringan, norma-norma dan kepercayaan sosial yang memungkinkan efisien dan efektifnya koordinasi dan kerjasama untuk keuntungan dan kebajikan bersama. Hasbullah (2006) sendiri mendefinisikan modal sosial sebagai sumberdaya yang dapat dipandang sebagai investasi untuk mendapatkan sumberdaya baru.
Lebih lanjut, pandangan dari beberapa ahli sosiologi dan antropologi di Indonesia menyatakan bahwa modal sosial mencakup potensi kelompok dan pola-pola hubungan antar individu dalam suatu kelompok dan antar kelompok dengan ruang perhatian pada jaringan sosial, norma, nilai dan kepercayaan antar sesama yang lahir dari anggota kelompok dan menjadi norma kelompok (Koentjaraningrat, 1990; Soekanto, 2002; Hasbullah, 2006). Perbedaan pada pola interelasi berikut konsekuensinya menyebabkan modal sosial terdiri dari modal sosial terikat (social capital bonding) dan modal sosial yang menjembatani (sosial capital bridging).

Semakin banyak karakter sosial budaya masyarakat yang mengarah kepada modal sosial yang menjembatani dapat diartikan kondisi sosial budaya masyarakat dimaksud semakin mendukung keberhasilan suatu pembangunan dan sebaliknya. Dalam aplikasinya pembangunan sektor perikanan, indikasi tipologi modal sosial di suatu masyarakat nelayan sangat diperlukan dalam memonitor program pembangunan berbasis masyarakat yang memiliki tujuan terbentuknya masyarakat yang partisipatif dan mandiri didalam pelaksanaan pembangunan.

Karakter sosial budaya yang menjadi ciri atau karakter modal sosial di masyarakat nelayan diketahui melalui pendekatan terhadap faktor-faktor internal dan eksternal yang mempengaruhi kebudayaan masyarakat (Jamasy, 2006). Faktor internal mencakup: (a) Pola organisasi sosial dalam suatu komunitas yang mencakup kepercayaan lokal, pola dan sistem produksi dan reproduksi serta politik lokal; dan (b) Norma dan nilai-nilai yang melekat dalam komunitas. Sedangkan faktor eksternal dapat dirangkum dalam pengaruh agama, pendidikan serta sistem dan hubungan politik dan pemerintahan dengan luar komunitas.

Faktor-faktor internal dan eksternal akan membentuk karakter dari modal sosial suatu masyarakat nelayan. Adapun karakter yang dibentuk terdiri dari kelompok-kelompok masyarakat yang ada, identitas kolektif suatu kelompok dan antar kelompok dalam suatu komunitas, tingkat partisipasi dan proaktif anggota dalam suatu kelompok 
dan antar kelompok, tujuan bersama dan kerjasama kelompok.

\section{Identifikasi Modal Sosial Masyarakat Nelayan}

\section{Lokasi dan Waktu Penelitian}

Penelitian ini dilakukan di Desa Gangga Dua, Kabupaten Minahasa Utara. Penelitian dan pengambilan data dilakukan selama bulan Juli-Agustus 2007. Desa Pasauran dipilih sebagai lokasi penelitian dengan pertimbangan memenuhi kriteriakriteria: 1) Mata pencaharian utama anggota masyarakat adalah nelayan dan 2) Wilayah perairan dengan sumberdaya perikanan yang sangat potensial.

\section{Jenis dan Sumber Data}

Data primer berupa deskripsi sosial budaya masyarakat nelayan setempat diperoleh dari informan yang merupakan aparat pemerintah setempat dan anggota masyarakat nelayan yang telah memiliki pemahaman cukup tentang kondisi sosial budaya masyarakat setempat. Data primer yang dikumpulkan mencakup (a) Nilai dan norma masyarakat lokal, didalamnya mencakup nilai dan norma lokal serta kandungan kebudayaan secara universal; (b) Kepercayaan lokal, mencakup pengaruh agama dari luar komunitas; (c) Pola dan sistem produksi dan reproduksi; dan (d) Politik lokal, mencakup hubungannya dengan sistem politik dan pemerintahan diluar komunitas.

Data sekunder adalah kondisi sosial budaya masyarakat setempat dan kondisi sumberdaya perikanan di perairan setempat. Data sekunder dikumpulkan dari laporan-laporan Dinas Perikanan dan Kelautan setempat serta hasil-hasil penelitian dari berbagai institusi akademis.

\section{Teknik Pengumpulan Data}

Data primer diperoleh melalui wawancara mendalam dengan informan yang dipilih secara snowball sampling. Informan dipilih menggunakan kriteria merupakan anggota masyarakat yang telah dianggap telah terlibat penuh dengan kehidupan sosial budaya masyarakat yang diteliti. Hubungan masyarakat yang diteliti dengan masyarakat luar diperoleh dari informan yang berasal dari Dinas Perikanan dan Kelautan setempat. Observasi atau pengamatan dilakukan secara langsung untuk mema- hami sosial budaya masyarakat disamping sebagai upaya verifikasi hasil wawancara. Data sekunder diperoleh melalui penelusuran literatur, baik di lokasi (Dinas Perikanan dan Kelautan setempat) maupun beberapa institusi akademis.

\section{Teknik Analisis Data}

Analisis data dilakukan dengan menggunakan pendekatan kualitatif (Bungin, 2003). Data dan informasi yang terkumpul dikelompokkan berdasarkan pengertian-pengertian yang dikembangkan untuk setiap faktor yang dikaji, yaitu: (a) Nilai dan norma masyarakat lokal; (b) Kepercayaan lokal; (c) Pola dan sistem produksi dan reproduksi; dan (d) Politik lokal. Pengkajian setiap faktor dibatasi ruang lingkupnya pada isu pengelolaan sumberdaya perikanan. Hal ini didasari pada permasalahan menurunnya sumberdaya perikanan sebagai modal komunitas yang pada akhirnya memerlukan bangkitan modal komunitas lainnya yaitu modal sosial. Hasil kajian keempat faktor selanjutnya menjadi gambaran karakter sosial budaya masyarakat nelayan yang merupakan indikator-indikator untuk menentukan tipologi modal sosial masyarakat. Data yang terkumpul akan dianalisis dengan menggunakan metode analisis deskriptif.

\section{HASIL DAN PEMBAHASAN}

\section{Keadaan Umum}

Desa Gangga Dua memiliki luas 135 hektar, terletak di ujung pantai Utara pulau Gangga, berbatasan langsung dengan Desa Gangga Satu. Di sebelah Utara langsung berbatasan dengan pulau Tindila (sebuah pulau seluas kurang lebih 10 hektar dan tidak berpenghuni, yang ditumbuhi tanaman kelapa). Diantara pulau Gangga dan Tindila terdapat selat kecil yang memiliki arus yang sangat kuat pada saat air pasang dan surut. Di sebelah Timur perairan relatif curam namun kedalamannya hanya 50 meter pada titik disebelah Timur Laut. Profil kedalaman mengindikasikan seperti kawah gunung berapi di bawah laut. Pemukiman penduduk terkonsentrasi di pantai dan relatif terlindung oleh hamparan terumbu karang di depan pemukiman. Di sebelah Selatan pemukiman terdapat hutan bakau 
relatif sedikit dan pendek akibat pemanfaatan yang intensif oleh masyarakat desa Gangga Dua. Vegetasi di belakang desa relatif sedikit, umumnya ditumbuhi alangalang dan pohon jambu mente yang tidak banyak.

Desa Gangga Dua, jumlah penduduk 877 jiwa yang terdiri dari laki-laki 443 jiwa dan perempuan 434 orang dengan jumlah kepala keluarga 220 KK. Secara lengkap jumlah penduduk Gangga Dua, menurut umur dan jenis kelamin dapat dilihat pada Tabel 1.

Tabel 1. Jumlah Penduduk Gangga Dua Menurut

\begin{tabular}{rcrrrr}
\multicolumn{6}{c}{ Umur, dan Jenis Kelamin. } \\
\hline No & $\begin{array}{c}\text { Kelompok } \\
\text { Umur }\end{array}$ & Pria & Wanita & $\Sigma$ & $\%$ \\
\hline 1 & $0-5$ & 53 & 52 & 105 & 11.97 \\
2 & $6-10$ & 54 & 53 & 107 & 12.20 \\
3 & $11-15$ & 51 & 50 & 101 & 11.52 \\
4 & $16-20$ & 49 & 50 & 99 & 11.29 \\
5 & $21-25$ & 48 & 47 & 95 & 10.83 \\
6 & $26-30$ & 45 & 41 & 86 & 9.81 \\
7 & $31-35$ & 39 & 39 & 78 & 8.89 \\
8 & $36-40$ & 31 & 29 & 60 & 6.84 \\
9 & $41-45$ & 27 & 27 & 54 & 6.16 \\
10 & $46-50$ & 26 & 25 & 51 & 5.82 \\
11 & $>51$ & 20 & 21 & 41 & 4.67 \\
\hline J u m I a h & 443 & 434 & 877 & 100.00 \\
\hline
\end{tabular}

Sumber: Profil Desa Gangga Dua, 2007

Dari Tabel di atas diperoleh gambaran bahwa penduduk Desa Gangga Dua, laki-laki berjumlah $50,51 \%$ dan perempuan $49,49 \%$. Hal ini menunjukkan tingkat kepadatan adalah 250 jiwa $\mathrm{km}^{2}$.

Penduduk terkonsentrasi di pesisir memanjang dari Selatan ke Utara kurang lebih sepanjang 500 meter, yang terbagi dalam 3 dusun. Diperkirakan luas perkampungan adalah 10 hektar. Tercatat $40 \%$ penduduk berasal dari suku Tidore, $40 \%$ Ternate, 10\% Sangihe, 5\% Minahasa dan $5 \%$ lagi terbagi atas suku Gorontalo dan Bolaang Mongondow. Penduduk desa ini memeluk agama Islam 90\% dan yang memeluk agama Kristen Protestan 10\%.

\section{Karakter Sosial Budaya Masyarakat Nelayan}

1. Faktor Nilai dan Norma Masyarakat

Nilai dan norma masyarakat dikaji berdasarkan pendekatan terhadap persepsi dan perilaku dan tindakan (Danim, 2003). Persepsi ini yang dikaji pada masyarakat yaitu persepsi yang terkait dengan pengelo- laan sumberdaya perikanan. Persepsi yang dikaji terdiri dari persepsi tentang: (a) hak kepemilikan sumberdaya laut; (b) batas wilayah penangkapan; dan (c) Perlunya konservasi sumberdaya perikanan. Konsistensi persepsi diuji berdasarkan perilaku dan tindakan masyarakat mengenai ketiga persepsi dimaksud.

Terkait dengan persepsi tentang hak kepemilikan sumberdaya laut diketahui bahwa masyarakat nelayan di desa ini beranggapan bahwa laut tidak ada yang memiliki. Laut hanya dimiliki oleh Sang Pencipta (Allah). Persepsi tentang hak kepemilikan sumberdaya laut ini tampak konsisten dengan persepsi masyarakat nelayan mengenai batas wilayah penangkapan. Masyarakat nelayan tidak mengenal adanya pembatasan atau batas wilayah operasional.

Persepsi masyarakat nelayan mengenai perlunya konservasi sumberdaya perikanan di sekitar mereka menunjukkan bahwa mereka tidak perlu melaksanakan upaya konservasi. Upaya konservasi merupakan urusan pemerintah. Persepsi tersebut tampak sangat dipengaruhi oleh aspek ekonomi. Bagi nelayan, upaya mencari nafkah lebih penting daripada upaya melaksanakan konservasi sumberdaya laut di sekitar mereka.

\section{Faktor Kepercayaan dan organisasi lokal}

Kepercayaan lokal dikaji melalui nilai-nilai dan norma agama atau kepercayaan yang dianut dan tercermin dalam kehidupan sosial masyarakat nelayan desa Gangga Dua. Sama halnya dengan masyarakat umumnya di daerah sekitarnya.

Saat kesulitan di musim paceklik, tidak ada dalam kelompok ritual keagamaan seperti pengajian yang mampu menggalang dana atau modal dan membantu antar anggotanya. Para nelayan anggota perkumpulan ritual keagamaan tersebut masih terjerat dalam pola permodalan melalui peminjaman uang kepada para tengkulak bunga tinggi atau dalam terminologi syariat Islam disebut dengan riba.

Secara komunitas, masyarakat juga tidak lagi melaksanakan suatu kegiatan kolektif yang terkait dengan agama ataupun kepercayaan yang mereka anut. Syukuran laut sebagai simbol budaya bahwa masya- 


\section{Identifikasi Modal Sosial Masyarakat Nelayan}

rakat nelayan mensyukuri segala hasil tangkapan sebagai pemberian dari Sang Pencipta tidak lagi dilakukan. Kepercayaan lokal yang dahulu dilakukan setahun sekali tidak lagi dilaksanakan karena dua faktor. Faktor pertama adalah adanya larangan dari kelompok ulama. Menurut penuturan informan disebutkan bahwa larangan tersebut muncul dari pandangan bahwa kegiatan syukuran laut merupakan suatu kegiatan yang bertentangan dengan ajaran agama. Faktor kedua adalah muncul dari pertimbangan ekonomi, yaitu masyarakat tidak mampu lagi untuk mengumpulkan uang sebagai dana pelaksanaan kegiatan tersebut. Hasil tangkapan yang seringkali sudah tidak lagi menguntungkan sedangkan kebutuhan ekonomi semakin meningkat membuat mereka tidak mampu untuk menyisihkan uang bagi pelaksanaan kegiatan pesta laut. Bagi masyarakat setempat, berdasarkan penuturan informan alasan yang terakhir ini merupakan masalah utama tidak lagi diselenggarakannya kegiatan pesta laut, sedangkan alasan pertama sebenarnya bukan alasan utama, jika secara keuangan mereka mampu maka mereka akan tetap melaksanakannya. Sebagian masyarakat menganggap golongan ulama tidak memiliki kekuatan dalam aktifitas keseharian. Mereka hanya ditempatkan sebagai pemimpin dalam urusan ibadah keagamaan saja oleh masyarakat.

Hasil penelitian di Desa Gangga dua menunjukkan bahwa hubungan sosial kemasyarakat masih sangat kuat dimana kehidupan sosial mereka begitu sangat erat. Hal ini muncul ketika ada salah seorang warga mengalami suatu musibah misalnya kematian maka tanpa dikomando masyarakat akan datang secara sukarela memberi bantuan baik dalam bentuk materi maupun dalam bentuk lainnya.

Di desa ini telah terbentuk suatu organisasi sosial kemasyarakatan khusus mengatur jika ada anggotanya yang meninggal dunia dan disebut dengan Rukun Duka. Rukun Duka ini telah lama terbentuk dan tetap terus dipertahankan secara turun temurun dan sampai saat ini masih berjalan dengan baik. Organisasi ini diatur secara resmi oleh pemerintah desa. Setiap anggota diwajibkan membayar uang Rp. 3000,serta membawa beras 1 liter ketika ada salah satu anggota yang meninggal dunia dan yang paling istimewa ternyata semua warga Desa Kinabuhutan yang sudah menikah menjadi anggota organisasi sosial Rukun Duka ini. Hasil wawancara dengan seorang anggota mengatakan bahwa organisasi seperti ini sangat membantu mereka ketika menghadapi musibah yang tidak bisa diduga seperti kematian.

Selain organisasi sosial Rukun Duka, ternyata terdapat juga organisasi sosial dibidang lain yaitu ketika menghadapi pesta perkawinan, perkumpulan muda mudi serta perkumpulan ibu-ibu Majelis Tahlim. Biasanya anggota organisasi ini terbatas dan tidak semua warga desa menjadi anggotanya. Struktur organisasi dari perkumpulan ibu-ibu Majelis Tahlim terdiri dari ketua, wakil ketua, sekretaris, bendahara dan anggota (ibu-ibu yang aktif dalam pengajian).

Organisasi di bidang pendidikan Desa Gangga Dua, yaitu Komite Sekolah. Komite Sekolah adalah organisasi pendidikan yang ada di setiap sekolah. Organisasi ini melaksanakan kegiatan berupa pencarian dana guna pembangunan fisik sekolah. Struktur organisasi Komite Sekolah terdiri dari ketua, wakil ketua, sekretaris, bendahara dan anggota (orang tua murid dari sekolah bersangkutan).

Tingkat pendidikan masyarakat Desa Gangga Dua secara umum masih rendah. Ini terlihat dari data bahwa sebagian besar penduduknya hanya tamatan Sekolah Dasar kemudian Sekolah Menengah Pertama. Hal ini disebabkan karena sarana pendidikan Yang tersedia di desa ini hanyalah satu buah SD Impres dan SMP terbuka yang mulai menerima siswanya pada Tahun 1995. Ketika akan melanjutkan studi ke tingkat SMU, mereka harus ke Likupang sebagai Ibukota Kecamatan dan tentu harus mengeluarkan biaya yang cukup besar sebagai biaya transportasi dan ini sangat membebani para orangtua mereka.

Selain organisasi-organisasi tersebut di atas, ada juga terbentuk organisasi dalam bentuk arisan yaitu dalam bentuk bahan bagunan yang membantu anggotanya ketika akan membangun rumah. Arisan ini dirasa sangat unik, karena jarang ada di suatu desa dan ternyata ada di desa yang letaknya cukup jauh dari pusat perekonomian. Ini menunjukkan bahwa keinginan untuk 
maju dan membangun dari masyarakat desa ini cukup besar. Struktur organisasi ini sama dengan organisasi-organisasi lainnya, yaitu terdiri dari ketua, sekretaris, bendahara dan anggota.

Lapisan sosial atau stratifikasi sosial tetap ada di desa ini namun secara keseluruhan tidak terlalu menyolok atau nampak. Ini juga tidak mempengaruhi hubungan sosial diantara mereka. Tingkat kekerabatan mereka masih cukup kuat dan merupakan ciri dari desa yang masih mengutamakan unsur-unsur sosial kemasyarakatan seperti saling membantu ketika mereka membutuh bantuan ketika kena musibah kematian walaupun hal ini dilakukan dengan tidak ada keterikatan. Organisasi duka di desa Gangga Dua secara tersirat sebenarnya ada, tetapi organisasi ini tidak secara resmi ada, karena tidak ada struktur organisasi yang terdiri dari ketua, sekretaris, bendahara dan anggota-anggota. Sehingga ketika terjadi kejadian duka, secara spontan seluruh warga desa akan melakukan aktifitas membantu warga yang kena duka cita.

Tabel 2. Mata Pencaharian Penduduk Gangga Dua.

\begin{tabular}{rlrr}
\hline No & Mata Pencaharian & \multicolumn{1}{c}{$\%$} \\
\hline 1 & Pegawai negeri/guru & 5 & 2,27 \\
2 & Petani & 5 & 2,27 \\
3 & Nelayan & 190 & 86,36 \\
4 & Pedagang/Tibo-tibo & 5 & 2,27 \\
5 & Tukang/buruh & 5 & 2,27 \\
6 & Lain-lain & 10 & 4,55 \\
\hline \multicolumn{4}{r}{} \\
\hline
\end{tabular}

Sumber: Data Primer (2007).

\section{Faktor Pola dan Sistem Produksi dan Reproduksi}

Masyarakat di daerah ini memiliki profesi sebagai nelayan dan mengerjakan pertanian. Alat tangkap yang mereka miliki dan operasikan menggunakan soma giop (pukat cincin kecil). soma pajeko (pukat cincin), funae, pancing dan rompon. Jenis alat tangkap ini hanya memiliki daerah operasi kurang dari 3 mil laut dari pantai dengan trip yang bersifat harian, namun ada beberapa yang menangkap ikan lebih dari 3 mil jauhnya dengan menggunakan motor tempel.

Meskipun mereka melakukan kegiatan penangkapan dengan nelayan dari luar daerah yang menggunakan alat tangkap yang lebih modern, namun belum tampak ada upaya nelayan setempat mengadopsi alat tangkap nelayan daerah lain. Jika dirunut, ketidaktertarikan untuk mengganti alat tangkap lebih dikarenakan aspek ekonomi, yaitu terbatasnya akses permodalan untuk meningkatkan teknologi dalam usaha penangkapan mereka.

Minimnya mata pencaharian alternatif juga lebih dikarenakan faktor keterbatasan internal yaitu rendahnya tingkat pendidikan dan keterampilan. Keterbatasan tersebut menyebabkan pekerjaan yang dilakukan oleh masyarakat nelayan di luar sektor perikanan lebih kepada pekerjaan yang mengandalkan fisik dan dengan modal kecil atau tidak memerlukan modal, seperti bertani, buruh tani dan buruh bangunan.

Replikasi sistem produksi tampaknya memerlukan bantuan dari pihak luar. Masyarakat nelayan, baik secara individu maupun kolektif, belum mampu untuk mencoba melakukan suatu sistem produksi dari daerah lain yang mampu meningkatkan kesejahteraan mereka.

Modal yang digunakan dalam satu kali operasi dengan menggunakan alat tangkap ini cukup besar, sebab alat tangkap ini menyerap tenaga kerja 15 - 20 orang per unit penangkapan. Oleh sebab itu untuk satu kali operasi penangkapan ikan, diharapkan setelah kembali ke desa membawah hasil yang cukup menguntungkan bagi rumah tangga nelayan. Sedangkan untuk Desa Talise Tambun umumnya kegiatan penangkapan ikan dilakukan dengan menggunakan perahu dan jenis alat tangkap yang sederhana. Selain itu ada juga penduduk yang bekerja di perusahaan budidaya kerang mutiara. Gerak perekonomian di desa ini lebih dinamis. Setiap waktu untuk transportasi laut dari desa ke ibukota kecamatan lancar setiap hari. Nelayan memasarkan hasil tangkapannya ataupun hasil pertanian mereka seperti pisang, ubi dan kelapa dalam jumlah yang cukup banyak ke pasar Likupang.

Dari hasil penelitian diperoleh data pendapatan nelayan berasal dari usaha perikanan dan kegiatan di luar perikanan. Pendapatan dari luar usaha perikanan juga terbagi dua yaitu pendapatan dari sektor pertanian dan pendapatan dari kegiatan di luar. Namun sebagian besar pendapatan nelayan berasal dari usaha perikanan. Data pendapatan nelayan dari sektor perikanan 
nleh selıırıh annonta kelıarna vann hekerja Identifikasi Modal Sosial Masyarakat Nelayan 3

Tabel 3. Pendapatan Responden Setiap Bulan dari Sektor Perikanan.

\begin{tabular}{rrrrrr}
\hline No & \multicolumn{2}{c}{$\begin{array}{c}\text { Kisaran Pendapatan } \\
\text { (Rp.000,-) }\end{array}$} & \multicolumn{1}{c}{$\boldsymbol{~} \%$} \\
\hline 1 & 200 & - & 400 & 7 & 5,83 \\
2 & 410 & - & 600 & 20 & 16,67 \\
3 & 610 & - & 800 & 61 & 50,83 \\
4 & 810 & - & 1.000 & 11 & 9,17 \\
5 & 1.100 & - & 1.200 & 2 & 1,67 \\
6 & 1.210 & - & 1.400 & 2 & 1,67 \\
7 & 1.410 & - & 1.600 & 6 & 5,00 \\
8 & 1.610 & - & 1.800 & 3 & 2,50 \\
9 & 1.810 & - & 2.000 & 4 & 3,33 \\
10 & & $>$ & 2.100 & 4 & 3,33 \\
\hline $\mathrm{J}$ u m I a h & & & 120 & 100,00 \\
\hline
\end{tabular}

Sumber : Data Primer (2007).

Hasil penelitian terhadap tingkat pengeluaran per bulan dari nelayan desa Gangga Dua, yaitu sebagai berikut.

Pengeluaran bulanan untuk nelayan di desa Kinabuhutan bervariasi mulai dari terendah sampai yang tertinggi. Pengeluaran untuk makanan bervariasi dari Rp. 150.000,- sampai Rp. 300.000,-. Rata-rata pengeluaran untuk bahan makanan per kepala keluarga Rp. 225.000,-; pengeluaran untuk pakaian rata-rata Rp. 500.000,-, perumahan Rp. 5.000,-, pendidikan Rp $20.000,-$, pengeluaran untuk kesehatan $R p$. 20.000 ,- dan pengeluaran lainnya $\mathrm{Rp}$. 20.000 ,-. Pengeluaran bulanan nelayan Desa Talise Tambun bervariasi, untuk bahan makanan mulai yang terendah Rp. 100.000 ,- sampai Rp. 500.000,-, jadi ratarata pengeluaran untuk bahan makanan Rp. $250.000,-$, pakaian Rp 35.000,-, pendidikan Rp. 40.000,-, perumahan Rp. 10.000,-, kesehatan Rp. 30.000,- dan lainlainya Rp. 50.000,-. Di desa Gangga Dua tingkat pengeluaran bulanan untuk bahan makanan rata-rata per kepala keluarga $\mathrm{Rp}$ $250.000,-$, pendidikan Rp. $50.000,-$, perumahan Rp. 15.000,-, kesehatan Rp. 30.000,- dan lain-lain Rp. 50.000,-.

\section{Faktor Politik lokal}

Faktor politik di suatu masyarakat terkait dengan aspek kepemimpinan dan proses pengambilan keputusan yang terjadi, dalam hal ini kepemimpinan dan proses pengambilan keputusan yang terjadi dikaitkan dengan potensinya untuk meningkatkan kesejahteraan masyarakat nelayan.
Dari aspek kepemimpinan, masyarakat nelayan menilai kepemimpinan berdasarkan wibawa dan kemampuan yang dimiliki oleh seseorang (Siagian, 2003). Bagi masyarakat nelayan, kewibawaan adalah kemampuan seseorang untuk mempengaruhi opini masyarakat terhadap fenomena sosial yang ada, sedangkan kemampuan adalah kemampuan seseorang dari aspek ekonomi yang diindikasikan oleh semakin banyaknya orang (nelayan) yang bergantung kepadanya.

Pada masyarakat nelayan, karakteristik kepemimpinan yang dimaksud menggiring kepada figur-figur atau tokoh-tokoh yang berlandaskan pada kemampuan dari aspek ekonomi. Tokoh-tokoh ini yang sesungguhnya memiliki status pekerjaan sebagai juragan-juragan pembeli hasil tangkapan, sangat berperan dalam hal penyelesaian konflik yang terkait dengan kegiatan ekonomi (penangkapan di laut) dan pelaksanaan kegiatan pesta syukuran laut. Kewenangan tokoh-tokoh ini tidak menyentuh hingga kegiatan atau aktifitas keseharian.

Sistem politik lokal ini tidak berhubungan dengan sistem politik dan pemerintahan yang ada di negara. Pengaruh pemberdayaan masyarakat melalui program pembangunan yang diharapkan muncul dari adanya kolektifitas antara masyarakat dengan pemerintah sulit terbangun. Pemimpin formal (pemerintah) di tingkat desa atau yang bertugas di komunitas atau masyarakat nelayan seringkali tidak dapat berpengaruh terhadap pengaturan kehidupan sosial maupun ekonomi masyarakat nelayan.

\section{Tipologi Modal Sosial Masyarakat Nelayan}

Menurut Hasbullah (2006) modal sosial berdasarkan karakter sosial budaya masyarakat terdiri dari dua jenis, yaitu modal sosial terikat dan modal sosial yang menjembatani. Perbedaan keduanya dapat ditemui melalui penggambaran karakterkarakter sosial budaya di masyarakat yang terkait dengan karakter setiap modal sosial.

Modal sosial terikat dicirikan oleh (Soekanto, 2002; Hasbullah, 2006): (a) Kelompok, dalam konteks ide, relasi dan perhatian, lebih berorientasi ke dalam dibandingkan ke luar. Ragam masyarakat atau individu yang menjadi anggota kelompok ini 
umumnya homogen, misalnya seluruh anggota kelompok berasal dari suku atau pemeluk agama yang sama; (b) Perhatian terfokus pada upaya menjaga nilai-nilai yang turun-temurun telah diakui dan dijalankan sebagian dari tata perilaku dan perilaku moral dari suku atau entitas sosial tersebut. Mereka cenderung konservatif dan lebih mengutamakan solidarity making daripada hal-hal yang lebih nyata untuk membangun diri dan kelompok sesuai dengan tuntutan nilai-nilai dan norma masyarakat yang lebih terbuka.

Kajian terhadap deskripsi faktor-faktor sosial budaya yang terkait dengan indikator modal sosial dapat dijelaskan sebagai berikut:

a. Nilai dan norma yang sesungguhnya dapat mendukung sisi kelestarian sumberdaya perikanan sebagai modal keberlanjutan usaha mereka di usaha penangkapan ternyata tidak dapat menjadi suatu modal hubungan antara mereka dengan pihak luar, dalam hal ini, dapat dikatakan mereka masih tergolong sebagai masyarakat yang tertutup.

b. Berdasarkan inkonsistensi antar agama yang dianut beserta ajaran-ajarannya dengan perilaku masyarakat dalam usaha mereka (kuatnya ikatan patronklien dan kuatnya peran bank keliling) menunjukkan rendahnya hubungan antara kelompok masyarakat berdasarkan kepercayaan atau religi dengan kelompok masyarakat berdasarkan kegiatan ekonomi. Hal ini menyiratkan karakter suatu masyarakat yang tergolong tertutup.

c. Homogenitas mereka yang tinggi, yaitu sebagian besar berprofesi nelayan maupun pekerjaan lain yang terkait, juga membuat mereka dan sistem produksinya (kegiatan perikanan) masih cenderung tertutup.

d. Ketertutupan mereka pada perubahanperubahan yang diharapkan dan berasal dari pihak luar (pemerintah) bahkan dari kelompok-kelompok lain di dalam masyarakat tersebut. Hal ini menyiratkan karakter masyarakat yang tertutup.

e. Kuatnya pengaruh tokoh informal yang tidak disertai dengan kuatnya hubungan tokoh-tokoh tersebut dengan pihak luar yang sangat berpotensi untuk menggerakkan perekonomian dan kehidupan sosial masyarakat menunjukkan karakter masyarakat tertutup.

\section{KESIMPULAN}

\section{Kesimpulan:}

- Kajian sosial budaya terhadap nilai dan norma, kepercayaan lokal, sistem produksi dan reproduksi serta politik lokal diketahui bahwa masyarakat nelayan di Desa Gangga Dua, Kabupaten Minahasa Utara masih merupakan masyarakat dengan karakter modal sosial terikat (social capital bonding). Tipologi modal sosial ini sangat dipengaruhi oleh nilainilai dan norma dari aspek ekonomi yang dimiliki dan dilakukan oleh masyarakat dalam kehidupan sehari-harinya. Hal ini berdampak pada struktur sosial yang terbentuk dalam kehidupan ekonomi masyarakat nelayan yang ada pada saat ini menjadi lebih berorientasi pada hubungan antar anggota dalam satu kelompok lebih banyak terfokus pada hal-hal yang terkait dengan aspek ekonomi. Hubungan antar kelompok di sisi lain sangat lemah, baik di dalam masyarakat maupun dengan pihak luar.

- Berdasarkan hasil analisis terhadap masyarakat nelayan tersebut dapat disimpulkan bahwa mereka memiliki tipologi modal sosial terikat beserta penyebabnya menyiratkan perlunya kebijakan dalam rangka meningkat modal sosial di masyarakat nelayan tersebut. Kebijakan dimaksud adalah perbaikan struktur sosial yang terkait dengan kehidupan ekonomi masyarakat nelayan. Melalui kebijakan ini, diharapkan hubungan antar anggota dalam satu kelompok tidak hanya terfokus pada masalah ekonomis dan hubungan antar kelompok akan lebih terjalin kuat.

- Organisasi sosial yang ada di Desa Gangga Dua adalah Rukun Duka, Musyawarah Kekeluargaan Masyarakat Desa, Pesta Perkawinan, Perkumpulan Muda-Mudi, Perkumpulan Ibu-lbu Majelis Tahlim, Arisan Bahan Bangunan, Usaha Simpan Pinjam dan Rukun Remaja.

\section{Saran}

- Perlu adanya penguatan modal dan pendampingan manajemen usaha penang- 
kapan ikan tradisional untuk dapat memanfaatkan makcimal nntenci cımberIdentifikasi Modal Sosial Masyarakat Nelayan

- Perlu dipikirkan lembaga keuangan yang ada di desa Gangga Dua, untuk memudahkan masyarakat untuk mengakses modal.

- Organisasi sosial masyarakat yang ada di desa Gangga Dua perlu dipertahankan karena hubungan sosial kemasyarakat masih sangat kuat dimana kehidupan sosial mereka begitu sangat erat.

\section{DAFTAR PUSTAKA}

Balai Besar Riset Sosial Ekonomi. 2005. Indikator Kinerja Pembangunan Sektor Kelautan dan Perikanan: Executive Summary. BBRSE. Jakarta. 43 hal.

Bungin, B. 2003. Analisis Data Penelitian Kualitatif. Pemahaman Filosofis dan Metodologis ke Arah Penguasaan Model Aplikasi. PT. Raja Grafindo Persada. Jakarta. 254 hal.

Cernea, M.M. 1988. Sosiologi Untuk ProyekProyek Pembangunan, dalam M.M. Cernea (Ed). Mengutamakan Manusia Dalam Pembangunan; Variabel-Variabel Sosiologi di dalam Pembangunan Pedesaan. Publikasi Bank Dunia. Penerjemah; B.B.Teku. Universitas Indonesia Press. Jakarta. Hal: 3-26
Danim, S. 2003. Metode Penelitian Untuk IImu-IImu Perilaku. Penerbit Bum Aksara. Jakarta. 235 hal.

Departemen Kelautan dan Perikanan 2006. Bahan Rapat Kerja Menteri Kelautan dan Perikanan dengan Komisi IV DPR RI tanggal 27 Februari 2006. Departemen Kelautan dan Perikanan. Jakarta.

Hasbullah, J. 2006. Social Capital (Menuju Keunggulan Budaya Manusia Indonesia), Penerbit MR-United Press Jakarta.

Jamasy, O., 2004. Keadilan. Pemberdayaan dan Penanggulangan Kemiskinan. Penerbit Belantika. Jakarta. 171 hal.

Koentjaraningrat. 1990. Pengantar IImu Antropologi. Rineka Cipta. Bandung. 391 hal.

Mantjoro, E. 1990. Metodologi Penelitian. Diktat Fakultas Perikanan Unsrat. Manado.

Mantjoro, E. 1997. Sejarah Penduduk dan Lingkungan Hidup Desa Talise. Konsultan Sosio-Ekonomi, Proyek Pengelolaan Sumberdaya Wilayah Pesisir. UNSRAT Manado.

Siagian, S.P. 2003. Teori dan Praktek Kepemimpinan. PT Rineka Cipta. Jakarta. 192 hal.

Soekanto, S. 2003. Sosiologi: Suatu Pengantar. PT. Raja Grafindo Persada. Jakarta. 466 hal.

Supardi. 2001. Metodologi Penelitian Ekonomi dan Bisnis. PT . Press Jogjakarta. 